Jack J. Ligtenberg

Hella F. Borggreve

Arjanne Stemerdink

Jan G. Zijlstra

\section{Subcutaneous glucose measurements and glucose regulation (?)}

Accepted: 26 August 2009

Published online: 10 February 2010 (C) The Author(s) 2010. This article is published with open access at

Springerlink.com

Sir: Andrea Stoszkova et al. [1] conclude, based on a correlation coefficient of 0.69 comparing subcutaneous glucose values (Guardian RT) and blood glucose values (Central Laboratory) in 15 patients, that subcutaneous devices should not be used in critically ill patients. However, Holzinger et al. [2] in the
August issue report a good correlation between subcutaneous and arterial glucose values, even in critically ill patients treated with norepinephrine.

We also evaluated the accuracy and feasibility of a comparable continuous subcutaneous glucose monitoring system (CGMS System Gold, Medtronic Minimed) and found a correlation coefficient of 0.87 with the point-of-care blood gas/glucose analyzer ABL 715 (Radiometer Medical, Copenhagen, Denmark), which we validated in ICU patients previously [3]. We drew 786 arterial blood samples from 60 consecutive ICU patients, of whom 37 patients received vaso-active medication (only norepinephrine) and 13 patients were treated with steroids. Blood glucose ranged from 2.2 to $20.1 \mathrm{mmol} / \mathrm{l}$. In the Clarke error grid (Fig. 1), 85.1\% of measurements were in zone A (clinically accurate, leading to correct and safe treatment decisions), $13.2 \%$ were in zone B (clinically acceptable), $0.13 \%$ were in zone $\mathrm{C}$, and $1.5 \%$ were in zone D. Zone D means

Distribution

A: $85.13 \%$, B: $13.21 \%$

C: $0.13 \%$, D: $1.52 \%$, E: $0.00 \%$

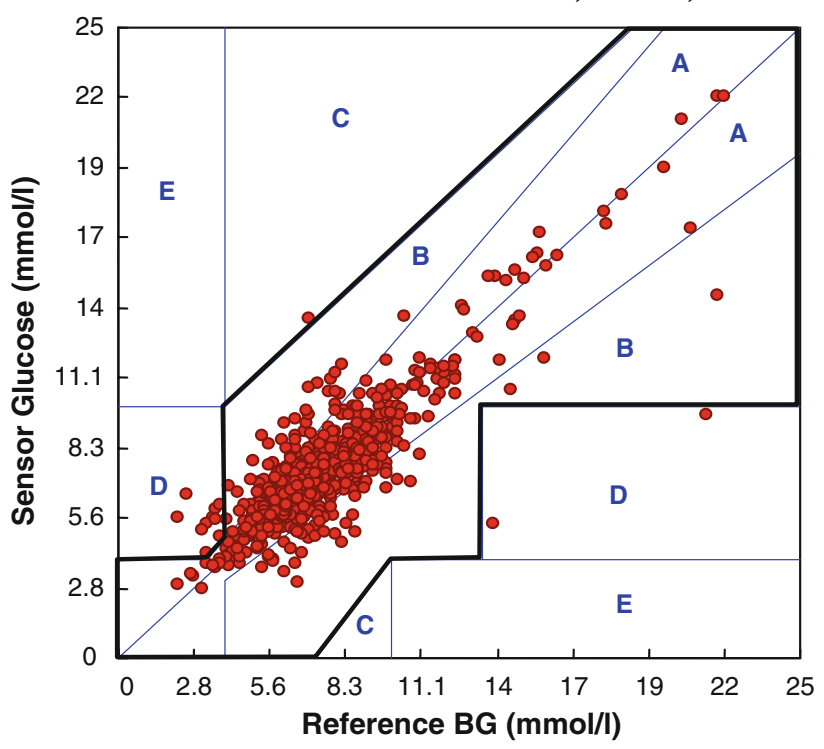

Fig. 1 Clarke error-grid analysis

failure-to-detect (high or low blood glucose) errors, resulting in failure to treat either low or high blood glucose results appropriately. The readings in zone D were found in nine patients, of whom eight were treated with vasopressors. One could argue thatwith a correlation coefficient of 0.87 and $98.3 \%$ of glucose values in the clinically acceptable zones-rejection of s.c. glucose determination in the ICU seems premature.

On the other hand, looking more precisely at zone $\mathrm{D}$ of the Clarke error grid (Fig. 1), a difference of nearly $4 \mathrm{mmol} / \mathrm{l}$ in the lower glucose zone (reference $2.8 \mathrm{mmol} / \mathrm{l}$ versus s.c. sensor $6.5 \mathrm{mmol} / \mathrm{l}$ ) observed in one patient could have severe consequences in this individual patient, if this results in an inappropriate rise in insulin dose. Unlike other diagnostic procedures, which usually are interpreted in conjunction with additional findings, a single glucose measurement has direct consequences for treatment, with potentially detrimental effects.

In other words, tight glucose regulation in ICU patients using a subcutaneous device may lead to more severe adverse events than the zone interpretation of the error grid suggests. The fact that we now have safe computerized protocols, which give excellent glucose regulation with a very low chance of hypoglycemic events [4], adds to the feeling that for glucose regulation in critically ill patients only the best pointof-care glucose analyzer and protocol should be used [5]. In an era where the beneficial effect of tight glucose regulation is questioned we cannot afford the introduction of treatmentrelated morbidity.

Open Access This article is distributed under the terms of the Creative Commons Attribution Noncommercial License which permits any noncommercial use, distribution, and reproduction in any medium, provided the original author(s) and source are credited. 


\section{References}

1. Stoszkova A, Dostal P, Musil F, Smahelova A, Zadak Z, Cerny V (2009)

Blood and tissue glucose level in critically ill patients: a comparison of different methods of measuring interstitial glucose levels. Intensive Care Med 35:1318

2. Holzinger U, Warszawska J, Kitzberger R, Herkner H, Metnitz PG, Madl C (2009) Impact of shock requiring norepinephrine on the accuracy and reliability of subcutaneous continuous glucose monitoring. Intensive Care Med 35:1383-1389
3. Corstjens AM, Ligtenberg JJ, Horst ICC, J. J. Ligtenberg $(\bowtie) \cdot$ J. G. Zijlstra Spanjersberg R, Lind JSW, Tulleken J, Meertens JH, Zijlstra JG (2006)

Accuracy and feasibility of point-of-care and continuous blood glucose analyzing in critically ill ICU patients. Crit Care 10:R135

4. Vogelzang M, Loef BG, Regtien JG, van der Horst IC, van Assen H, Zijlstra F, Nijsten MW (2008) Computer-assisted glucose control in critically ill patients. Intensive Care Med 34:1421-1427

5. Vogelzang M, Ligtenberg JJ (2007) Practical aspects of implementing tight glucose control in the ICU. Curr Opin Clin Nutr Metab Care 10:178-180
Critical Care, University Medical Center Groningen (UMCG), Groningen,

The Netherlands

e-mail: j.j.m.ligtenberg@int.azg.nl; jackligtenberg@hotmail.com

Tel.: +31-50-3616161

Fax: +31-50-3613216

H. F. Borggreve

Critical Care, OLVG, Amsterdam, The Netherlands

\section{A. Stemerdink}

Anesthesiology, University Medical Center Groningen (UMCG), Groningen,

The Netherlands 